\title{
Genome-wide gene expression analysis of anguillid herpesvirus 1
}

\author{
Steven J van Beurden ${ }^{1,2,4^{*}}$, Ben PH Peeters ${ }^{1}$, Peter JM Rottier ${ }^{2}$, Andrew J Davison ${ }^{3}$ and Marc Y Engelsma ${ }^{1}$
}

\begin{abstract}
Background: Whereas temporal gene expression in mammalian herpesviruses has been studied extensively, little is known about gene expression in fish herpesviruses. Here we report a genome-wide transcription analysis of a fish herpesvirus, anguillid herpesvirus 1, in cell culture, studied during the first 6 hours of infection using reverse transcription quantitative PCR.

Results: Four immediate-early genes - open reading frames 1, 6A, 127 and 131 - were identified on the basis of expression in the presence of a protein synthesis inhibitor and unique expression profiles during infection in the absence of inhibitor. All of these genes are located within or near the terminal direct repeats. The remaining 122 open reading frames were clustered into groups on the basis of transcription profiles during infection. Expression of these genes was also studied in the presence of a viral DNA polymerase inhibitor, enabling classification into early, early-late and late genes. In general, clustering by expression profile and classification by inhibitor studies corresponded well. Most early genes encode enzymes and proteins involved in DNA replication, most late genes encode structural proteins, and early-late genes encode non-structural as well as structural proteins.

Conclusions: Overall, anguillid herpesvirus 1 gene expression was shown to be regulated in a temporal fashion, comparable to that of mammalian herpesviruses.

Keywords: Anguillid herpesvirus 1, Temporal gene expression, Kinetic class, RT-qPCR
\end{abstract}

\section{Background}

Herpesvirus gene expression occurs in a temporally regulated fashion involving three major gene sets $[1,2]$. The first set consists of the immediate-early genes, which are defined as those that are transcribed in the absence of $d e$ novo protein synthesis. These genes regulate the subsequent expression of other genes. The next set, the early genes, encodes the enzymes involved in nucleotide metabolism and replication of the viral genome, and several envelope glycoproteins. The final set, the late genes, requires viral DNA synthesis for expression and encodes viral structural proteins. There is usually no clear boundary between early and late expression, and an intermediate leaky-late or early-late group has been proposed. Although this widely-used classification of herpesvirus genes may

\footnotetext{
* Correspondence: steven.vanbeurden@ulg.ac.be

${ }^{1}$ Central Veterinary Institute, part of Wageningen UR, P.O. Box 65, 8200 AB, Lelystad, The Netherlands

2Department of Infectious Diseases and Immunology, Faculty of Veterinary Medicine, Utrecht University, P.O. Box 80.165, 3508 TD, Utrecht, The Netherlands

Full list of author information is available at the end of the article
}

not fully reflect the subtle regulation of viral gene expression in infected cells, it helps understanding of the viral replication cycle, gene functions, virus-host interactions and possibilities for control of disease.

Herpesvirus genes have traditionally been classified kinetically on the basis of individual expression studies in cell culture [3]. Application of specific chemicals to inhibit selectively the expression of early and/or late genes has contributed to the classification and functional characterization of genes. More recently, genome-wide microarray and reverse transcription quantitative (RT-q) PCR expression studies have been performed for several mammalian herpesviruses in the family Herpesviridae [4-11]. However, little is known about expression in members of the family Alloherpesviridae, which infect amphibians and fish.

For channel catfish virus (ictalurid herpesvirus 1, IcHV1) the expression kinetics of a limited number of open reading frames (ORFs), namely ORF3, ORF5, ORF5/6, ORF6, ORF8A/9, ORF9, ORF12/13, ORF39 and ORF46 [12-14], has been studied in cell culture by northern blot analyses. 
Transcriptional regulation of all 14 ORFs in the terminal direct repeat of the genome has been analysed by northern blot analysis in cell culture [15] and by RT-PCR and Southern blot analysis in vivo [16]. For this small number of IcHV1 ORFs, temporal expression patterns similar to that of mammalian herpesviruses have been demonstrated. In addition, transcription in cell culture of 20 ORFs in koi herpesvirus (cyprinid herpesvirus 3, CyHV3) has been demonstrated by RT-PCR [17].

Anguillid herpesvirus 1 (AngHV1) causes a haemorrhagic disease and is associated with increased mortality rates in the Japanese eel (Anguilla japonica) and European eel (Anguilla anguilla) [18,19]. In this first report on genome-wide transcription of an alloherpesvirus, we characterized expression in cell culture of AngHV1 ORFs that are predicted to encode functional proteins by using RT-qPCR, which permits sensitive quantitation of specific RNAs [20,21]. Expression of early and late ORFs was selectively blocked by a protein synthesis inhibitor, and expression of late ORFs was inhibited by a viral DNA polymerase inhibitor. The genes were classified on the basis of their expression patterns in the presence of these inhibitors. We identified four putative immediate-early ORFs, and - on the basis of their transcription profiles clustered all but three of the remaining 125 ORFs into early, early-late and late gene categories. The analysis relied on an AngHV1 map [GenBank:FJ940765.3] that is a substantial improvement on the original map derived from bioinformatic analysis of the complete genome sequence [22]. The updated map was derived from a deep-sequencing transcriptome study [23], and included redefined ORFs and experimentally supported polyadenylation (polyA) sites. The deep sequencing study also showed that, overall, $98.5 \%$ of late transcription of AngHV1 ORFs is directed by the sense DNA strand.

\section{Results and discussion}

One-day old eel kidney 1 (EK-1) cell monolayers [24] in 6-well plates were pre-incubated with either virus growth medium (VGM), VGM containing protein synthesis inhibitor cycloheximide (CHX), or VGM containing viral DNA polymerase inhibitor phosphonoacetic acid (PAA). After the pre-incubation, the cells were infected with the Dutch AngHV-1 isolate CVI500138 [25] at a multiplicity of infection (MOI) of $1050 \%$ tissue culture infective dose $\left(\mathrm{TCID}_{50}\right)$ /cell in the appropriate VGM. RNA was extracted at $\mathrm{t}=0,1,2,4$, and $6 \mathrm{~h}$ post infection (hpi). Potential contaminating DNA was removed, polyA RNA was extracted and reverse transcribed into cDNA. SYBR Green quantitative (q)PCR reactions were carried out for all AngHV1 ORFs, taking a reaction for the reference $\beta$-actin gene of European eel [26] into account in every qPCR run for each time point. Based on the efficiency of amplification (E) for each primerset, relative expression ratio (R)
$[7,27]$, change in relative gene expression $\left(R_{\Delta}\right)$, inhibitory effect of $\mathrm{CHX}$ at $\mathrm{t}=4$ and $\mathrm{t}=6 \mathrm{hpi}\left(\mathrm{R}_{\mathrm{i}-\mathrm{CHX}}\right)$, and inhibitory effect of PAA at $t=6$ hpi $\left(R_{i-P A A}\right)$ were calculated.

\section{Reproducibility}

Experiments in which cells were untreated were carried out three times, and experiments in which cells were treated with PAA or CHX were carried out twice. The $\beta$-actin reference gene $\mathrm{Ct}$-values were highly reproducible; the mean value \pm standard deviation of all measurements $(n=656)$ of all experiments was $16.73 \pm 2.14$ (coefficient of variation $=12.8 \%$ ).

Relative expression ratios were calculated independently for each experiment, and the mean and standard deviation values were subsequently calculated for all ORFs and time points. The average coefficient of variation for $\mathrm{R}_{\mathrm{i}-\mathrm{CHX}}$ for the non-inhibited ORFs at $\mathrm{t}=4$ and $\mathrm{t}=6$ hpi was $21.8 \%$ and $22.7 \%$, respectively. The average coefficient of variation for $\mathrm{R}_{\mathrm{i} \text {-PAA }}$ for all ORFs at $\mathrm{t}=6 \mathrm{hpi}$ was $16.8 \%$.

\section{Families of 3 -coterminal transcripts}

Although herpesvirus genes generally have individual promotors, it is not uncommon for a single polyA site to be shared by two or more genes arranged as a 3'-coterminal family [28]. In the deep-sequencing transcriptome study of AngHV1 [23], 32 such families were identified. With regard to the current study, the RT-qPCR signals detected for the 58 ORFs that are not in 3'-coterminal families and the 32 ORFs that are located at the 5'-ends of 3'-coterminal families can be considered accurate. However, signals detected for the remaining 36 ORFs might be mixed with those from upstream ORFs, and a more tentative interpretation is implicit in the results discussed below.

\section{AngHV1 gene expression}

Gene expression was detected at some time point for all predicted functional protein-coding ORFs in the AngHV1 genome. In general, levels were absent or very low at $t=1$ and $\mathrm{t}=2 \mathrm{hpi}$ and increased exponentially during the monitored period. ORF1, ORF6A, ORF127 and ORF131 were the first genes becoming detectable, they already showed significant expression at $\mathrm{t}=2 \mathrm{hpi}$. Maximum expression was measured at $t=6$ hpi for all ORFs, except for ORF1, ORF86 and ORF130, which peaked at $\mathrm{t}=4 \mathrm{hpi}$.

The net change in transcription at each time interval or $\mathrm{R}_{\Delta}$ was calculated for each gene (Additional file 1: Table S1). The genes were clustered based on their $R_{\Delta}$-values, and ten groups were distinguished (Figure 1 ). $R_{\Delta}$-graphs are shown for all gene groups (Figure 2), with the unique expression kinetics of ORF1, ORF6A, ORF127 and ORF131 combined in one (Figure $2 \mathrm{~A}$, group IE). The $\mathrm{R}_{\Delta}$-graphs of the upstream located 3'-coterminal ORFs are represented by dashed lines. 
The $\mathrm{R}_{\Delta}$ of the 12 members of groups E1-4 is characterized by a very low value at $R_{2}-R_{1}$, a steep increase between $R_{2}-R_{1}$ and $R_{4}-R_{2}$, and a decrease or stabilization at $R_{6}-R_{4}$ (Figure 2B-E). Differentiation between the $\mathrm{E}$ groups is based on the $R_{\Delta}$-value at $R_{6}-R_{4}$, which varies from practically zero (group E1) to more or less similar at $R_{4}-R_{2}$ and $\mathrm{R}_{6}-\mathrm{R}_{4}$ (group E4).

The $\mathrm{R}_{\Delta}$ of members of groups EL1 and EL2 is characterized by a very low value at $R_{2}-R_{1}$, and a more or less linear increase between $R_{2}-R_{1}$ and $R_{6}-R_{4}$ (Figure $2 F-G$ ). The 9 members of group EL1 show a slightly earlier but less steep increase of $R_{\Delta}$ than the 12 members of group EL2. Both members of the ORF109 gene family (ORF109 and ORF125) belong to group EL1, with ORF125 being identified as a low-abundant envelope protein [29].

Most of the genes fall into group $L(n=89)$. The $R_{\Delta}$-value is zero or very low at $R_{2}-R_{1}$, very low or low at $R_{4}-R_{2}$, and almost maximal at $\mathrm{R}_{6}-\mathrm{R}_{4}$ (Figure $2 \mathrm{H}$ ). Group $\mathrm{L}$ comprises both members of the ORF3 gene family (ORF3 and ORF14), both members of the ORF11 gene family (ORF11 and ORF12), three members of the ORF13 gene family (ORF16, ORF17 and ORF24), three members of the ORF68 gene family (ORF69, ORF70 and ORF73), both members of the deoxyguanosine kinase (dGK) gene family (ORF79 and ORF123), and three members of the tumour necrosis factor receptor (TNFR) gene family (ORF108, ORF121 and ORF124).

In the analysis described above, we followed the RTqPCR-based approach used to study gene expression by Tombácz et al. [7] in pseudorabies virus (PRV; a mammalian herpesvirus in subfamily Alphaherpesvirinae, family Herpesviridae). In general, gene expression profiles are highly comparable for AngHV1 and PRV. The AngHV1 and PRV immediate-early genes and the PRV large latency transcript demonstrate unique expression profiles, genes in group $\mathrm{E}$ show maximum increase of gene expression between $t=2$ and $t=4 \mathrm{hpi}$, genes in group $\mathrm{L}$ show maximum increase of gene expression between $t=4$ and $t=6 \mathrm{hpi}$, and genes in group EL demonstrate an intermediate expression profile. AngHV1 comprises about twice as much ORFs as PRV, which mainly add up to the EL and L groups.

\section{Immediate-early transcripts of AngHV1}

Inhibition of de novo protein synthesis by $\mathrm{CHX}$ resulted in an inhibition of relative gene expression $\left(\mathrm{R}_{\mathrm{i}-\mathrm{CHX}}\right)$ of $>66 \%$ at $\mathrm{t}=4$ and of $>91 \%$ at $\mathrm{t}=6 \mathrm{hpi}$ for all but 4 ORFs. ORF6A and ORF127 showed almost no inhibition at $t=4$ and $t=6$ hpi (Figure 3). ORF1 demonstrated an increase in relative expression of 1.3 at $t=4$ and of 7.6 at $t=6$ hpi. ORF131 exhibited an increase in relative expression of 3.8 at $t=4$ and of 4.7 at $\mathrm{t}=6 \mathrm{hpi}$.

In cells not treated with inhibitors, these 4 immediateearly ORFs showed unique expression profiles that were clearly distinct from those of other ORFs (group IE). No imputed amino acid sequence similarities with ORFs in other alloherpesviruses were detected [22]. ORF127 has been shown to encode a low-abundant structural tegument protein [29].

\section{Early and early-late transcripts of AngHV1}

Inhibition of viral DNA polymerase by PAA resulted in an inhibition of gene expression $\left(\mathrm{R}_{\mathrm{i}-\mathrm{PAA}}\right)$ at $\mathrm{t}=6 \mathrm{hpi}$ for all but two ORFs (Additional file 2: Table S2). In the presence of PAA, the relative expression of ORF1 was doubled, and that of ORF6A was not affected. Table 1 shows the mean and standard deviations of $\mathrm{R}_{\mathrm{i} \text {-PAA-values in the presence }}$ of PAA at $t=6$ hpi for the 61 ORFs of AngHV1 for which a putative function has been described (listed on the basis of their $\mathrm{R}_{\mathrm{i}-\mathrm{PAA}}$-values), with the kinetic classes of ORFs potentially compromised by 3 '-coterminality marked with asterisks.

Inhibition of gene expression by PAA ranges from about $30 \%$ for ORF87 to $99 \%$ for ORF95. A comparable range was described previously for PRV [7]. The ORFs are classified into kinetic classes on the basis of their $\mathrm{R}_{\mathrm{i} \text {-PAA-values, }}$ with arbitrarily set threshold values. The typical early gene ORF10, encoding the ATPase subunit of terminase, was chosen as the last early gene, and ORF18, encoding a structural tegument protein, as the first early-late gene. ORF75, encoding thymidylate synthetase, was denoted as the last of the early-late genes, and ORF34, encoding a structural tegument protein, as the first of the late genes. There was no clear boundary between early, early-late, and late genes based on their $\mathrm{R}_{\mathrm{i} \text {-PAA-values. }}$

A total of 17 early genes were identified (Additional file 2: Table S2). Almost half of these showed a distinct expression profile in the untreated samples (members of groups E1-4), characterized by the largest increase of $R_{\Delta}$ between $R_{2}-R_{1}$ and $R_{4}-R_{2}$. Among the early genes are those involved in DNA replication (ORF55) and DNA packaging (ORF10), genes encoding a guanosine triphosphatase (GTPase) (ORF15), a serine-threonine protein kinase (ORF87), a protein encoding a TNFR domain (ORF101), and two lowabundant tegument proteins (ORF14 and ORF39). Early genes identified for IcHV1 included the thymidine kinase gene (IcHV1 ORF5), a protein kinase (IcHV1 ORF14), and two putative membrane proteins (IcHV1 ORF6 and IcHV1 ORF8) [14,15].

A total of 37 early-late genes were identified, with inhibition of expression values intermediate between those of early and late genes (Additional file 2: Table S2). In samples not treated with inhibitors, 4 of the early-late genes were grouped into one of the E groups, and 10 genes were classified in one of the EL groups. Functions have been predicted for 17 of the early-late genes (Table 1). These consist of 9 genes encoding non-structural proteins and 8 encoding structural proteins. Among the non-structural group are 


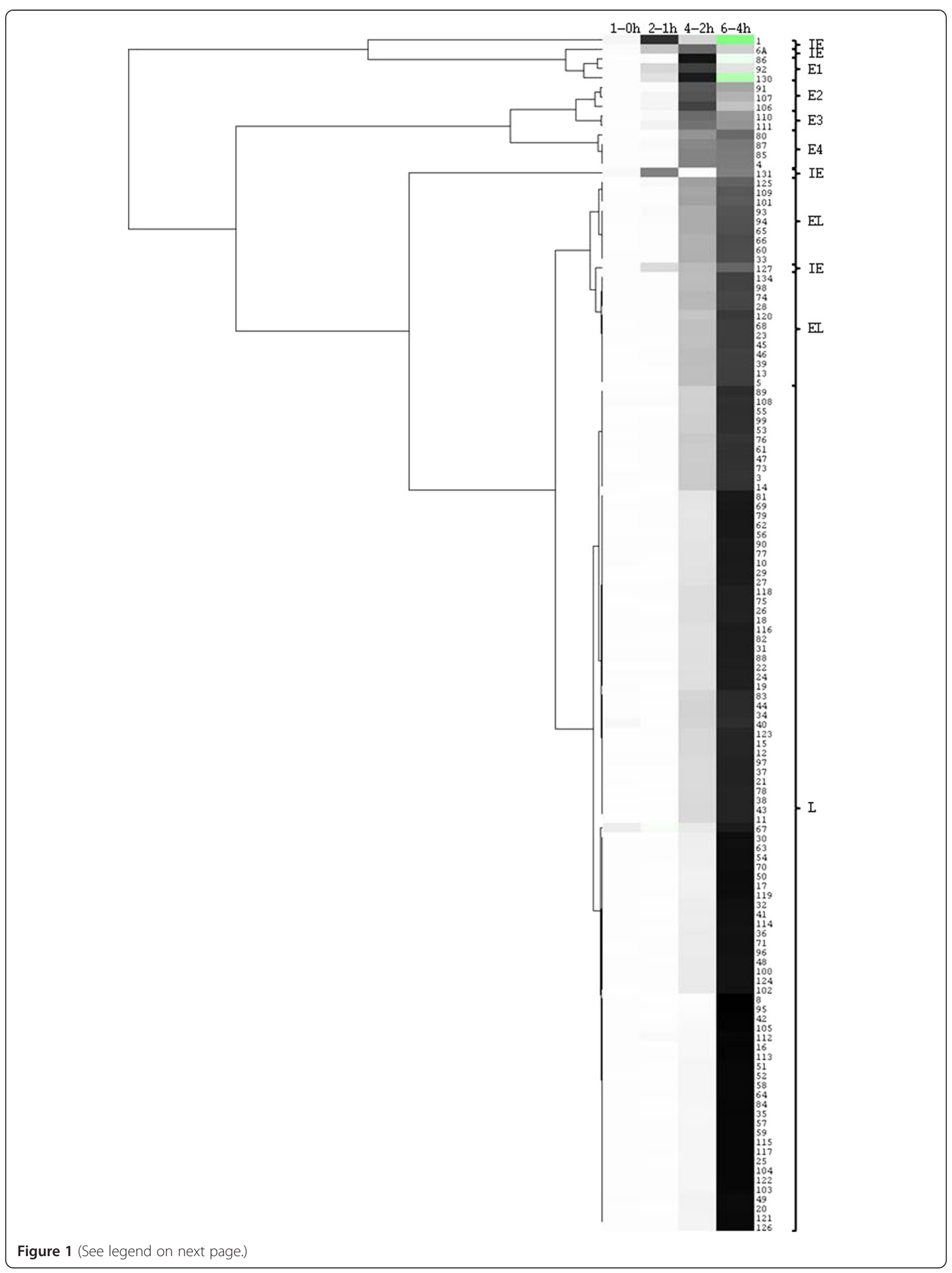


(See figure on previous page.)

Figure 1 Cluster analysis of AngHV1 ORFs on the basis of $\mathbf{R}_{\Delta}$-values. Complete linkage hierarchical clustering analysis of the $R_{\Delta}$-values of all AngHV1 ORFs for the time points $R_{1}-R_{0}, R_{2}-R_{1}, R_{4}-R_{2}$ and $R_{6}-R_{4}$. Java TreeView pixel settings were: contrast $=1.0$, positive $=$ black, zero $=$ white, negative $=$ green. Clades were flipped as to visualize genes in order of expression from top to bottom. Accolades indicate clusters of genes with comparable gene expression profiles, corresponding to the groups shown in Figure 2.

proteins involved in DNA replication (ORF21 and ORF37) and enzymes involved in nucleic acid metabolism. Among the structural early-late gene proteins are 4 tegument and 4 envelope proteins, but no capsid proteins. For IcHV1, a membrane protein (IcHV1 ORF7), a tegument protein (IcHV1 ORF11) and a zinc-binding protein (IcHV1 ORF12) were shown to specify both early and late transcripts [15]. Our findings are in general accordance with the properties of proteins encoded by early and early-late genes of mammalian herpesviruses.

\section{Late transcripts of AngHV1}

A total of 68 late genes were identified (Additional file 2: Table S2), 6 of which were clustered into one or other of the EL groups, and 62 of which were grouped in the $\mathrm{L}$ group. Functions have been assigned to 33 of the late gene proteins (Table 1), 28 of which involve roles as structural proteins. All 7 capsid proteins, as well as 14 tegument proteins and 7 envelope proteins, were identified as being encoded by late genes. Similarly, the three late genes identified for IcHV1 encode the major capsid protein (IcHV1 ORF39) and two membrane proteins (ORF10 and ORF46) [14,15]. Two of the putative hostimmunomodulatory proteins of AngHV1, namely an interleukin 10 homolog encoded by ORF25 [30] and a protein containing a TNFR domain encoded by ORF124 [22], were also identified as being encoded by late genes.

\section{Location of expression in the AngHV1 genome}

A stringent summary of the kinetic classes of AngHV1

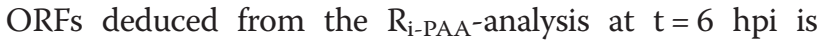
shown in Figure 4, with the 36 ORFs potentially compromised by 3'-coterminality and the three ORFs for which no data were obtained left blank. The immediate-early ORFs are located within the terminal direct repeats (ORF1 and ORF6A) and near the right end of the unique region (ORF127 and ORF131). The two or three immediate-early genes of IcHV1 identified in a comparable way are also located in the terminal direct repeats [13-15]. The early, early-late and late genes are seemingly distributed randomly throughout the genome.

\section{Differences in expression kinetics of AngHV1 genes with and without inhibitors}

In the present study, we classified the AngHV1 genes on the basis of their expression patterns in the presence of specific inhibitors selectively blocking the expression of early and/or late genes. This classification is not fully consistent with the clustering of genes on the basis of their expression profiles in the absence of an inhibitor. Whereas all immediate-early genes also showed unique expression profiles in cells not treated with inhibitors (IE group), and most late genes were expressed later than the other genes (L group), only half of the early and one-third of the early-late genes clustered in the $\mathrm{E}$ and EL groups, respectively. The latter finding may partly be explained by the incomplete blockage of the expression of late genes by the viral DNA polymerase inhibitor, but may also reflect the more complex regulation of viral gene expression during normal infection. The genes with marked differences in expression kinetics between both approaches are of interest for further functional characterization.

\section{Conclusions}

We have studied the kinetics of gene expression in AngHV1 by genome-wide transcription analyses using RT-qPCR. Four immediate-early genes were identified on the basis of their unique gene expression profiles in cells not treated with inhibitors, and on the basis of their unchanged or increased gene expression in the presence of a protein synthesis inhibitor. Additional characterization of these genes is required to determine their potential roles in the regulation of gene expression. On the basis of inhibition of gene expression in the presence of a viral DNA polymerase inhibitor, 17 early genes, 37 early-late genes and 68 late genes were identified. This classification broadly complied with cluster analysis of the genes based on their changes in relative gene expression in untreated samples. Our findings on the broad functions of genes assigned to different kinetic classes are in accordance with those from a more limited exercise with IcHV1, and may be extrapolated to related alloherpesviruses. Comparable to mammalian herpesviruses, most of the early and earlylate genes encode proteins involved in viral DNA replication, enzymes involved in nucleic acid metabolism, and several envelope glycoproteins. Most of the late genes encode structural proteins. Hence, we suggest that, despite the virtual absence of detectable genetic similarities between the herpesvirus families, fish herpesviruses of the family Alloherpesviridae exhibit patterns of temporally regulated gene expression that are similar to those of mammalian herpesviruses in the family Herpesviridae. 

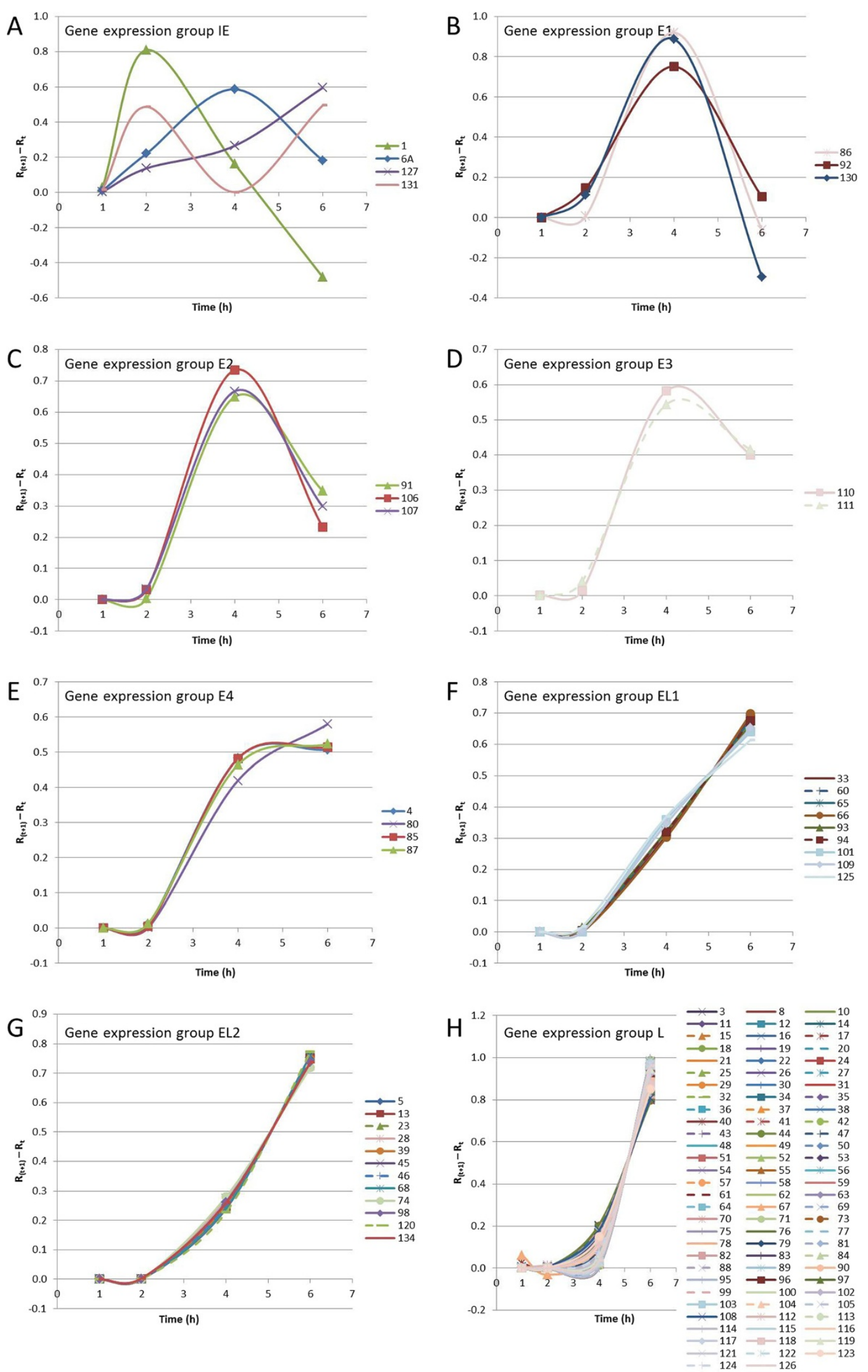

Figure 2 (See legend on next page.) 
(See figure on previous page.)

Figure 2 Plots of groups of AngHV1 ORFs with comparable $\mathbf{R}_{\Delta}$-value-based gene expression profiles. All AngHV1 genes were grouped on the basis of cluster analysis of their gene expression profiles based on their $R_{\Delta}$-values over the four time intervals. Gene expression group names correspond to clustering in Figure 1. Expression profile graphs of ORFs potentially compromised by 3'-coterminality are dashed.

\section{Methods}

\section{Cell culture}

The Dutch AngHV1 isolate CVI500138 [25] was propagated in one-day old $\sim 80 \%$ confluent eel kidney 1 (EK-1) cell monolayers [24]. The cells were cultured in monolayers in sterile plastic culture flasks (Falcon, BD Biosciences, Bedford, MA, USA) with virus growth medium (VGM), consisting of Leibovitz's L-15 medium (Gibco, Invitrogen by Lifetechnologies, Carlsbad, CA, USA) with $2 \%$ (v/v) fetal bovine serum (FBS, Bodinco, Alkmaar, The Netherlands), $0.075 \%(\mathrm{w} / \mathrm{v}) \mathrm{NaHCO}_{3}, 2 \mathrm{mM}$ L-glutamine (Gibco) and antibiotics (0.012\% (w/v) kanamycin (Sigma-Aldrich, St. Louis, MO, USA) and $270 \mathrm{IE} / \mathrm{ml}$ penicillin G (Astellas Pharma, Tokyo, Japan)) at $26^{\circ} \mathrm{C}$ in a $5 \% \mathrm{CO}_{2}$-incubator (Nuaire, Plymouth, MN, USA). For virus propagation on 6-well plates (Cellstar, Greiner bio-one, Frickenhausen, Germany), $0.26 \%$ instead of $0.075 \%$ (w/v) $\mathrm{NaHCO}_{3}$ was used.

\section{Virus infections}

One-day old EK-1 monolayers in 6-well plates were washed once and pre-incubated for $1 \mathrm{~h}$ with either $5 \mathrm{ml}$ of VGM, $5 \mathrm{ml}$ of VGM containing $100 \mu \mathrm{g} / \mathrm{ml}$ protein synthesis inhibitor cycloheximide (CHX, Calbiochem, Merck, Darmstadt, Germany), or with $5 \mathrm{ml}$ of VGM containing $400 \mu \mathrm{g} / \mathrm{ml}$ viral DNA polymerase inhibitor phosphonoacetic acid (PAA, Sigma-Aldrich). After the pre-incubation, the cells were infected with AngHV1 at a multiplicity of infection (MOI) of $1050 \%$ tissue culture infective dose

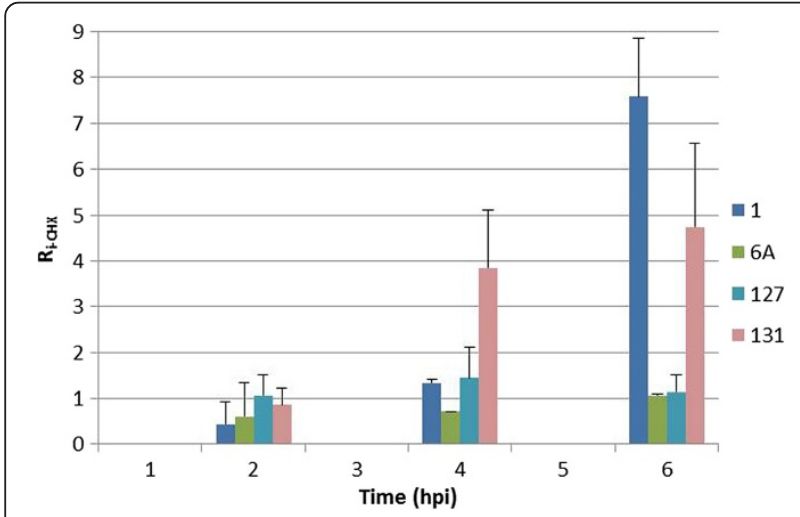

Figure 3 Relative inhibition of immediate-early gene expression in the presence of $\mathbf{C H X}\left(\mathbf{R}_{\mathbf{i}-\mathrm{CHX}}\right)$. Inhibitory effect of $\mathrm{CHX}$ on gene expression $\left(\mathrm{R}_{\mathrm{i}-\mathrm{CHX}}\right)$ at $\mathrm{t}=2,4$ and 6 hpi. Only the four ORFs that exhibited no significant inhibition of gene expression are shown (ORF1, ORF6A, ORF127 and ORF 131). Standard deviations of

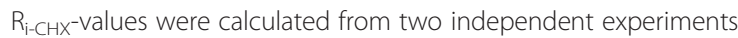
and are indicated by error bars.
$\left(\mathrm{TCID}_{50}\right) /$ cell in $2 \mathrm{ml}$ of the appropriate VGM $(\mathrm{t}=0)$. After a $30 \mathrm{~min}$ incubation period, cells were washed thrice with the appropriate VGM formulation and incubated for another $30 \mathrm{~min}, 1.5,3.5$ or $5.5 \mathrm{~h}$. Infections were performed in triplicate with native VGM, and in duplicate for PAA- and CHX-containing VGM.

\section{mRNA extraction}

RNA was extracted at $\mathrm{t}=0$ (non-infected control), 1, 2, 4 , and $6 \mathrm{~h}$ post infection (hpi). Infected cells were washed once with the appropriate VGM formulation, and cells were lysed directly in the culture dish by adding $1 \mathrm{ml}$ Trizol Reagent (Invitrogen). RNA was extracted according to manufacturer's protocol, and dissolved in $200 \mu \mathrm{l}$ RNase-free water (Sigma-Aldrich) with $2 \mu \mathrm{l} \mathrm{RNa-}$ seOUT recombinant ribonuclease inhibitor (Invitrogen). RNA concentration was checked by spectrophotometry using a Nanodrop ND-1000 (Thermo Fisher Scientific, MA, USA).

Potential contaminating DNA was removed by treatment with DNase I (Roche, Basel, Switzerland). Twenty units of DNase I $(2 \mu \mathrm{l})$ were added to a maximum of $50 \mu \mathrm{g}$ total RNA $(87.5 \mu \mathrm{l}), 10 \mu \mathrm{l} 10 \times$ Incubation buffer and 10 units RNaseOUT, and incubated for $20 \mathrm{~min}$ at $31^{\circ} \mathrm{C}$ at $550 \mathrm{rpm}$ on a thermomixer (Eppendorf, Hamburg, Germany). DNase I was inactivated by adding $2 \mu \mathrm{l} 0.2 \mathrm{M}$ EDTA (pH 8.0) and heating for $10 \mathrm{~min}$ at $75^{\circ} \mathrm{C}$ at $550 \mathrm{rpm}$ on a thermomixer. The concentration of DNase-treated RNA in the samples was checked by spectrophotometry.

PolyA RNA was extracted using an Oligotex mRNA kit (Qiagen, Hilden, Germany). In brief, $90 \mu \mathrm{l}$ DNasetreated total RNA was used as starting material, following the manufacturer's instructions for the spin-column protocol. PolyA RNA was finally dissolved in $2 \times 75 \mu \mathrm{l}$ of buffer $\mathrm{OEB}$ at $70^{\circ} \mathrm{C}$. After cooling, $1.5 \mu \mathrm{l}$ RNaseOUT was added and the sample was stored at $-80^{\circ} \mathrm{C}$.

\section{Reverse transcription}

Reverse transcription (RT) was carried out using the TaqMan Reverse Transcriptase Reagent kit (Applied Biosystems by Lifetechnologies, Carlsbad, CA, USA). The total volume of RT mix prepared on ice was $100 \mu \mathrm{l}$ per reaction, containing $10 \mu \mathrm{l}$ RT buffer $(10 \times), 22 \mu \mathrm{l}$ $\mathrm{MgCl}_{2}(25 \mathrm{mM}), 20 \mu \mathrm{l} \mathrm{dNTP}$ mixture $(2.5 \mathrm{mM}$ of each dNTP), $5 \mu$ l oligo dT $(50 \mu \mathrm{M}), 2 \mu \mathrm{l}$ RNase Inhibitor $(20 \mathrm{U} / \mu \mathrm{l}), 2.5 \mu \mathrm{l}$ MultiScribe Reverse Transcriptase $(50 \mathrm{U} / \mu \mathrm{l}), 23.5 \mu \mathrm{l}$ DNase- and RNase-free water and $15 \mu \mathrm{l}$ polyA RNA as template. The thermal profile of the RT program consisted of $10 \mathrm{~min}$ 
Table 1 Expression of selected AngHV1 genes, sorted on the basis of their $R_{\mathrm{i}-\mathrm{PAA}}$-values at $\mathbf{t}=\mathbf{6} \mathrm{hpi}$

\begin{tabular}{|c|c|c|c|c|}
\hline $\mathrm{ORF}^{\mathrm{a}}$ & Mean $^{\text {b }}$ & STDEV $^{c}$ & Kinetic class $^{\mathrm{d}}$ & Function $^{\mathrm{e}}$ \\
\hline 1 & 1.800 & 0.475 & Immediate early & \\
\hline $6 \mathrm{~A}$ & 1.059 & 0.115 & Immediate early & \\
\hline 127 & 0.690 & 0.120 & Immediate early & \\
\hline 87 & 0.609 & 0.019 & Early & $\begin{array}{l}\text { Serine-threonine protein } \\
\text { kinase }\end{array}$ \\
\hline 39 & 0.529 & 0.057 & Early & Tegument protein \\
\hline $14^{*}$ & 0.522 & 0.022 & Early & Tegument protein \\
\hline 101 & 0.519 & 0.089 & Early & $\begin{array}{l}\text { Tumour necrosis factor } \\
\text { receptor domain }\end{array}$ \\
\hline 131 & 0.493 & 0.016 & Immediate early & \\
\hline $15^{*}$ & 0.462 & 0.074 & Early & Guanosine triphosphatase \\
\hline 55 & 0.457 & 0.004 & Early & DNA polymerase \\
\hline 10 & 0.442 & 0.156 & Early & $\begin{array}{l}\text { ATPase subunit of } \\
\text { terminase }\end{array}$ \\
\hline $18^{*}$ & 0.429 & 0.038 & Early/Late & Tegument protein \\
\hline 67 & 0.427 & 0.078 & Early/Late & Major glycoprotein \\
\hline 66 & 0.417 & 0.036 & Early/Late & Envelope protein \\
\hline 116 & 0.359 & 0.002 & Early/Late & $\begin{array}{l}\text { Ribonucleotide reductase } \\
\text { (large subunit) }\end{array}$ \\
\hline 123 & 0.340 & 0.039 & Early/Late & Deoxyguanosine kinase \\
\hline 78 & 0.329 & 0.032 & Early/Late & Envelope protein \\
\hline $37^{*}$ & 0.316 & 0.041 & Early/Late & DNA helicase \\
\hline 5 & 0.313 & 0.064 & Early/Late & $\begin{array}{l}\text { Deoxyuridine } \\
\text { thriphosphatase }\end{array}$ \\
\hline 108 & 0.308 & 0.011 & Early/Late & Envelope protein \\
\hline $77^{*}$ & 0.287 & 0.004 & Early/Late & Thymidylate kinase \\
\hline 38 & 0.271 & 0.023 & Early/Late & Tegument protein \\
\hline 90 & 0.264 & 0.007 & Early/Late & $\begin{array}{l}\text { Nucleoside diphosphate } \\
\text { kinase }\end{array}$ \\
\hline 83 & 0.263 & 0.073 & Early/Late & Large tegument protein \\
\hline 21 & 0.262 & 0.058 & Early/Late & Primase \\
\hline 29 & 0.259 & 0.025 & Early/Late & Uracil-DNA glycosylase \\
\hline $19^{*}$ & 0.253 & 0.005 & Early/Late & Tegument protein \\
\hline 75 & 0.246 & 0.034 & Early/Late & Thymidylate synthetase \\
\hline 34 & 0.242 & 0.028 & Late & Tegument protein \\
\hline 125 & 0.222 & 0.024 & Late & Envelope protein \\
\hline $43^{*}$ & 0.206 & 0.072 & Late & Tegument protein \\
\hline $32^{*}$ & 0.201 & 0.051 & Late & Tegument protein \\
\hline 71 & 0.199 & 0.023 & Late & Envelope protein \\
\hline $81^{*}$ & 0.196 & 0.013 & Late & Tegument protein \\
\hline 79 & 0.188 & 0.027 & Late & Deoxyguanosine kinase \\
\hline 40 & 0.185 & 0.038 & Late & Tegument protein \\
\hline $20^{*}$ & 0.179 & 0.002 & Late & Tegument protein \\
\hline $124^{*}$ & 0.174 & 0.012 & Late & $\begin{array}{l}\text { Tumour necrosis factor } \\
\text { receptor domain }\end{array}$ \\
\hline 119 & 0.170 & 0.028 & Late & Dihydrofolate reductase \\
\hline
\end{tabular}

Table 1 Expression of selected AngHV1 genes, sorted on the basis of their $\mathbf{R}_{\mathbf{i}-P A A}$-values at $\mathbf{t}=\mathbf{6} \mathbf{h p i}$ (Continued)

\begin{tabular}{|c|c|c|c|c|}
\hline $17^{*}$ & 0.162 & 0.020 & Late & Tegument protein \\
\hline 100 & 0.160 & 0.034 & Late & Capsid protein \\
\hline $36^{*}$ & 0.154 & 0.071 & Late & Capsid triplex protein 2 \\
\hline 114 & 0.153 & 0.025 & Late & Tegument protein \\
\hline 26 & 0.147 & 0.062 & Late & Tegument protein \\
\hline 24 & 0.145 & 0.076 & Late & Tegument protein \\
\hline 96 & 0.124 & 0.029 & Late & $\begin{array}{l}\text { Ribonucleotide reductase } \\
\text { (small subunit) }\end{array}$ \\
\hline 30 & 0.110 & 0.057 & Late & Tegument protein \\
\hline 49 & 0.090 & 0.013 & Late & Envelope protein \\
\hline 16 & 0.079 & 0.023 & Late & Tegument protein \\
\hline 115 & 0.070 & 0.013 & Late & Envelope protein \\
\hline $35^{*}$ & 0.068 & 0.011 & Late & Tegument protein \\
\hline 48 & 0.068 & 0.015 & Late & Capsid protein \\
\hline $57^{*}$ & 0.066 & 0.022 & Late & $\begin{array}{l}\text { Capsid protease-and- } \\
\text { scaffolding protein }\end{array}$ \\
\hline $25^{*}$ & 0.063 & 0.016 & Late & Interleukin 10 homolog \\
\hline 51 & 0.063 & 0.026 & Late & Envelope protein \\
\hline 103 & 0.057 & 0.012 & Late & Tegument protein \\
\hline $104^{*}$ & 0.050 & 0.007 & Late & Major capsid protein \\
\hline 126 & 0.031 & 0.008 & Late & Capsid protein \\
\hline $42^{*}$ & 0.024 & 0.001 & Late & Capsid triplex protein 1 \\
\hline 8 & 0.010 & 0.004 & Late & Envelope protein \\
\hline 95 & 0.010 & 0.000 & Late & $\begin{array}{l}\text { Envelope infectious } \\
\text { salmon anaemia virus } \\
\text { haemagglutinin-esterase } \\
\text { protein }\end{array}$ \\
\hline
\end{tabular}

a ORF numbering corresponds to van Beurden et al. [22]; only ORFs for which a putative function has been predicted are shown; ORFs from which the data are potentially compromised by 3 '-coterminality are marked with asterisks. ${ }^{b}$ Mean $\mathrm{R}_{\mathrm{i}-\mathrm{PAA}}$-values were calculated from two independent experiments. c Standard deviations of $\mathrm{R}_{\mathrm{i}-\mathrm{PAA}}$-values were calculated from two independent experiments.

${ }^{d}$ Immediate-early genes were classified on the basis of $\mathrm{CHX}$ inhibition experiments; boundaries between early, early-late and late genes are explained in the text.

e Gene functions were predicted based on similarity with known functional protein sequences [22], and on AngHV1 structural protein analyses by mass spectrometry [29].

incubation at $25^{\circ} \mathrm{C}, 30 \mathrm{~min} \mathrm{RT}$ at $48^{\circ} \mathrm{C}, 5 \mathrm{~min} \mathrm{RT}$ inactivation at $95^{\circ} \mathrm{C}$, and cooling to $4{ }^{\circ} \mathrm{C}$, and was performed in a 96-well GeneAmp PCR System 9700 (Applied Biosystems). For each polyA RNA sample, RT was carried out in duplicate, after which the cDNA was combined and diluted 1:5 in DNase- and RNase-free water and stored at $-20^{\circ} \mathrm{C}$.

\section{Quantitative PCR}

The total volume of the SYBR Green quantitative (q) PCR mix was $20 \mu \mathrm{l}$ per reaction, containing $10 \mu \mathrm{l}$ SYBR Green PCR Mix (Applied Biosystems), $0.8 \mu \mathrm{l}$ forward primer $(10 \mu \mathrm{M}), 0.8 \mu \mathrm{l}$ reverse primer $(10$ 


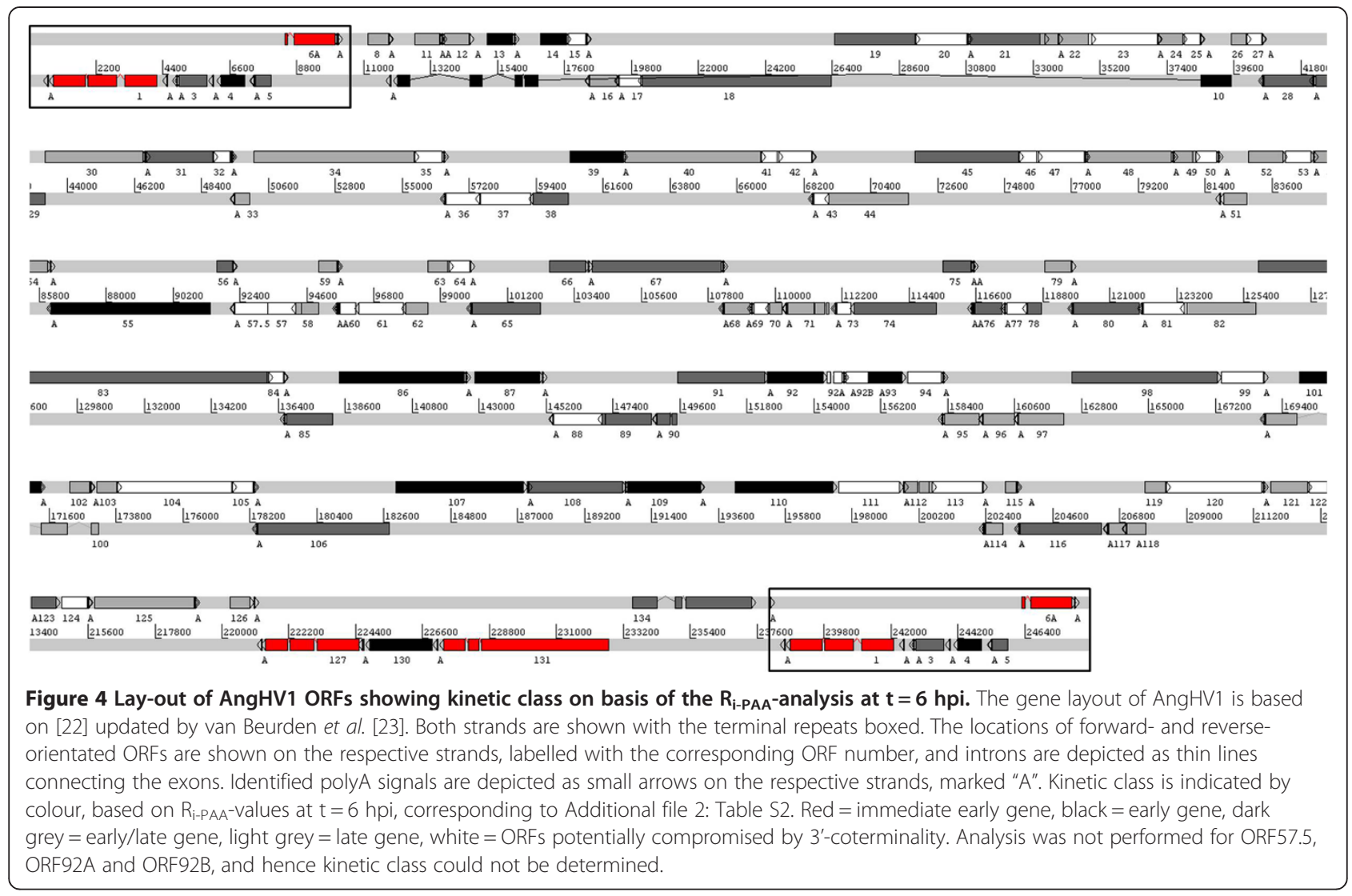

$\mu \mathrm{M}), 0.25 \mu \mathrm{l}$ Uracil-DNA Glycosylase (UDG, $5 \mathrm{U} / \mu \mathrm{l}$, New England Biolabs, Ipswich, MA, USA), $3.15 \mu \mathrm{l}$ super $\mathrm{Q}$ and $5 \mu \mathrm{l}$ diluted cDNA template. The thermal profile of the SYBR Green qPCR program consisted of $10 \mathrm{~min}$ at $37^{\circ} \mathrm{C}, 10 \mathrm{~min}$ at $95^{\circ} \mathrm{C}, 40$ cycles of $15 \mathrm{~s}$ at $95^{\circ} \mathrm{C}$ and $1 \mathrm{~min}$ at $60^{\circ} \mathrm{C}$, followed by a dissociation stage from $60^{\circ} \mathrm{C}$ to $95^{\circ} \mathrm{C}$ at the end of the run, and was carried out in a 7500 Fast Real-Time PCR system (Applied Biosystems) under Standard 7500 conditions. In every qPCR run, for each time point reactions for the reference $\beta$-actin gene of European eel (Anguilla anguilla) were analysed, using the primer set described by Aroua et al. [26].

\section{Primers}

Primers were designed for all AngHV1 ORFs, except for the newly predicted ORF57.5, ORF92A and ORF92B [23], using the Primer Express 3.0 program (Applied Biosystems) in the TaqMan and TaqMan MGB quantification mode, and evaluated using the Oligo Analyzer program v1.5 (Gene Link, Hawthorne, NY, USA). Primers are listed in Additional file 3: Table S3.

For all primer sets, specificity and efficiency were tested as described below. Viral DNA was extracted from purified AngHV1 virions [29] using the DNA blood mini kit (Qiagen) following the manufacturer's protocol. Tenfold dilution series were prepared from AngHV1 DNA in buffer AE (Qiagen), and, for all primer sets, standard curves over four orders of magnitude were tested in triplicate. Primer sets were also checked for the formation of nonspecific reactions with host cell DNA. Primer sets were considered valid if primers did not form nonspecific products in non-template controls, and if standard curve slopes were at least -3.8 . Average melting temperature ( $\mathrm{Tm}$-) values for each primer set were calculated from the efficiency tests. The efficiency of the $\beta$-actin reference gene primer set was determined to be 91.0\% from tenfold dilution series over four orders of magnitude from cDNA from an infection trial with native VGM and VGM containing PAA or CHX at different time points post infection.

\section{Data analyses}

Quantitative PCR data were analysed using the Sequence Detection Software version 1.4 program (Applied Biosystems) with the Auto baseline function and a threshold of 0.05. The means of the three Ct-values for each dilution point were calculated, and the efficiency of amplification (E) of each primer set was determined from the slope of the standard curves using the Microsoft Excel 2003 
program (Microsoft, Redmond, WA, USA), using the formula:

$$
E=10^{-1 / \text { slope }}
$$

The relative expression ratio (R) was calculated for each sample using the formula modified from Pfaffl et al. [27] by Tombácz et al. [7]:

$$
R=E_{\text {sample }}{ }^{\mathrm{Ct}[\text { sample max }]-\mathrm{Ct}[\text { sample] }]} / E_{\text {reference }}{ }^{\mathrm{Ct}[\text { [reference max }]-\mathrm{Ct}[\text { [reference }]}
$$

$E_{\text {sample }}$ refers to the efficiency of amplification of a particular primer set, $\mathrm{Ct}$ [sample max] refers to the maximal $\mathrm{Ct}$-value for that particular sample during the course of infection, $\mathrm{Ct}$ [sample] refers to any particular sample at a given time point, $E_{\text {reference }}$ refers to the efficiency of amplification of the $\beta$-actin reference gene primer set, $\mathrm{Ct}[$ reference $\max ]$ refers to the $\mathrm{Ct}$-value for the $\beta$-actin reference gene corresponding to $\mathrm{Ct}$ [sample max], and $\mathrm{Ct}$ [reference] refers to the $\mathrm{Ct}$-value for the $\beta$-actin reference gene corresponding to $\mathrm{Ct}$ [sample]. R-values, means and standard deviations were calculated for each sample using the Microsoft Excel 2003 program. The change in relative gene expression in untreated samples was calculated by subtracting the $\mathrm{R}$-value of a given time point from the previous time point:

$$
R_{\Delta}=R_{(t+1)}-R_{t}
$$

Genes were clustered on the basis of their $\mathrm{R}_{\Delta}$-values by using a complete linkage hierarchical clustering method with a centred correlation similarity metric, using the Cluster 3.0 computer program (M. Eisen, Stanford University, USA and M. de Hoon, University of Tokyo, Japan) and viewed with Alok Saldanha's Java TreeView v1.1.6r2. $\mathrm{R}_{\Delta^{-}}$-graphs of clustering genes were plotted using the Microsoft Excel program.

The inhibitory effect of $\mathrm{CHX}$ on gene expression $\left(\mathrm{R}_{\mathrm{i}-\mathrm{CHX}}\right)$ at $t=4$ and $t=6$ hpi and the inhibitory effect of PAA on gene expression $\left(\mathrm{R}_{\mathrm{i}-\mathrm{PAA}}\right)$ at $\mathrm{t}=6 \mathrm{hpi}$ were calculated using the formula of Pfaffl et al. [27].

\section{Additional files}

Additional file 1: Table S1. Net increase per time interval for each AngHV1 ORF $\left(R_{\Delta}\right)$.

Additional file 2: Table S2. Expression of AngHV1 genes, sorted on the

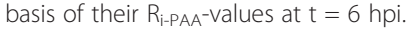

Additional file 3: Table S3. Sequences and efficiency of qPCR primers targeting 126 AngHV1 ORFs.

\section{Competing interests}

The authors declare that they have no competing interests.

\section{Authors' contributions}

SJvB designed the study, designed the primers, carried out the virus infections, mRNA extractions, RT, qPCR, data analyses and drafted the manuscript. BPHP and PJMR advised on the study design and manuscript.

AJD provided the updated AngHV1 map (including 3'-ends), advised on results interpretation and manuscript. MYE coordinated the study, advised on the study design and manuscript. All authors read and approved the final manuscript.

\section{Acknowledgements}

The authors thank Ineke Roozenburg and Michal Voorbergen-Laarman (Central Veterinary Institute (CVI) of Wageningen UR) for technical assistance in cell and virus culture. This study received financial support from the Dutch Ministry of Economic Affairs, Agriculture and Innovation.

\section{Author details}

${ }^{1}$ Central Veterinary Institute, part of Wageningen UR, P.O. Box 65, 8200 AB, Lelystad, The Netherlands. ${ }^{2}$ Department of Infectious Diseases and Immunology, Faculty of Veterinary Medicine, Utrecht University, P.O. Box 80.165, 3508 TD, Utrecht, The Netherlands. ${ }^{3} \mathrm{MRC}$-University of Glasgow Centre for Virus Research, Glasgow G11 5JR, UK. ${ }^{4}$ Current address: Immunology-Vaccinology (B43b), Department of Infectious and Parasitic Diseases, Faculty of Veterinary Medicine, University of Liège, 4000 Liège, Belgium.

Received: 24 May 2012 Accepted: 24 January 2013

Published: 6 February 2013

\section{References}

1. Pellet PE, Roizman B: The Family Herpesviridae: A Brief Introduction In Fields Virology. vol. 2, 5th edition. Edited by Knipe DM, Howley PM. Philadelphia: Wolters kluwer/Lippincott Williams \& Wilkins; 2007:2479-2497.

2. McGeoch DJ, Rixon FJ, Davison AJ: Topics in herpesvirus genomics and evolution. Virus Res. 2006, 117(1):90-104

3. Honess RW, Roizman B: Regulation of herpesvirus macromolecular synthesis, I. Cascade regulation of the synthesis of three groups of viral proteins. J. Virol. 1974, 14(1):8-19.

4. Stingley SW, Ramirez JJ, Aguilar SA, Simmen K, Sandri-Goldin RM, Ghazal P, Wagner EK: Global analysis of herpes simplex virus type 1 transcription using an oligonucleotide-based DNA microarray. J. Virol. 2000, 74(21):9916-9927.

5. Martinez-Guzman D, Rickabaugh T, Wu TT, Brown H, Cole S, Song MJ, Tong L, Sun R: Transcription program of murine gammaherpesvirus 68. J. Virol. 2003, 77(19):10488-10503.

6. Dittmer DP, Gonzalez CM, Vahrson W, DeWire SM, Hines-Boykin R, Damania B: Whole-genome transcription profiling of rhesus monkey rhadinovirus. J. Virol. 2005, 79(13):8637-8650.

7. Tombácz D, Tóth JS, Petrovszki P, Boldogkoi Z: Whole-genome analysis of pseudorabies virus gene expression by real-time quantitative RT-PCR assay. BMC Genomics 2009, 10:491.

8. Wagner EK, Ramirez JJ, Stingley SW, Aguilar SA, Buehler L, Devi-Rao GB, Ghazal P: Practical approaches to long oligonucleotide-based DNA microarray: lessons from herpesviruses. Prog. Nucleic Acid Res. Mol. Biol. 2002, 71:445-491.

9. Ebrahimi B, Dutia BM, Roberts KL, Garcia-Ramirez JJ, Dickinson P, Stewart JP, Ghazal P, Roy DJ, Nash AA: Transcriptome profile of murine gammaherpesvirus-68 lytic infection. J. Gen. Virol. 2003, 84(Pt 1):99-109.

10. Aguilar JS, Devi-Rao GV, Rice MK, Sunabe J, Ghazal P, Wagner EK: Quantitative comparison of the HSV-1 and HSV-2 transcriptomes using DNA microarray analysis. Virology 2006, 348(1):233-241.

11. Aguilar JS, Ghazal P, Wagner EK: Design of a herpes simplex virus type 2 long oligonucleotide-based microarray: global analysis of HSV-2 transcript abundance during productive infection. Methods Mol. Biol. 2005, 292:423-448.

12. Silverstein PS, Bird RC, van Santen VL, Nusbaum KE: Immediate-early transcription from the channel catfish virus genome: characterization of two immediate-early transcripts. J. Virol. 1995, 69(5):3161-3166.

13. Silverstein PS, van Santen VL, Nusbaum KE, Bird RC: Expression kinetics and mapping of the thymidine kinase transcript and an immediate-early transcript from channel catfish virus. J. Virol. 1998, 72(5):3900-3906.

14. Huang $S$, Hanson LA: Temporal gene regulation of the channel catfish virus (Ictalurid herpesvirus 1). J. Virol. 1998, 72(3):1910-1917.

15. Stingley RL, Gray WL: Transcriptional regulation of the channel catfish virus genome direct repeat region. J. Gen. Virol. 2000, 81(Pt 8):2005-2010. 
16. Stingley RL, Griffin BR, Gray WL: Channel catfish virus gene expression in experimentally infected channel catfish, Ictalurus punctatus (Rafinesque). J. Fish Dis. 2003, 26(8):487-493.

17. Dishon A, Davidovich M, llouze M, Kotler M: Persistence of cyprinid herpesvirus 3 in infected cultured carp cells. J. Virol. 2007, 81(9):4828-4836.

18. Sano M, Fukuda $H$, Sano T: Isolation and characterization of a new herpesvirus from eel. In Pathology in Marine Sciences. 1st edition. Edited by Perkins FO, Cheng TC. San Diego: Academic Press; 1990:15-31.

19. Haenen OLM, Dijkstra SG, Tulden PW, Davidse A, van Nieuwstadt AP, Wagenaar F, Wellenberg GJ: Herpesvirus anguillae (HVA) isolations from disease outbreaks in cultured European eel, Anguilla anguilla in the Netherlands since 1996. Bull Eur Ass Fish Pathol 2002, 22(4):247-257.

20. Mackay IM, Arden KE, Nitsche A: Real-time PCR in virology. Nucleic Acids Res. 2002, 30(6):1292-1305.

21. Papin J, Vahrson W, Hines-Boykin R, Dittmer DP: Real-time quantitative PCR analysis of viral transcription. Methods Mol. Biol. 2005, 292:449-480.

22. van Beurden SJ, Bossers A, Voorbergen-Laarman MH, Haenen OL, Peters S, Abma-Henkens MH, Peeters BP, Rottier PJ, Engelsma MY: Complete genome sequence and taxonomic position of anguillid herpesvirus 1 . J. Gen. Virol. 2010, 91(Pt 4):880-887.

23. van Beurden SJ, Gatherer D, Kerr K, Galbraith J, Herzyk P, Peeters BP, Rottier PJ, Engelsma MY, Davison AJ: Anguillid herpesvirus 1 transcriptome. J. Virol. 2012, 86(18):10150-10161.

24. Chen SN, Ueno Y, Kou GH: A cell line derived from Japanese eel (Anguilla japonica) kidney. Proc. Natl. Sci. Counc. Repub. China B 1982, 6:93-100.

25. van Nieuwstadt AP, Dijkstra SG, Haenen OL: Persistence of herpesvirus of eel Herpesvirus anguillae in farmed European eel Anguilla anguilla. Dis Aquat Org 2001, 45(2):103-107.

26. Aroua S, Weltzien FA, Le Belle N, Dufour S: Development of real-time RTPCR assays for eel gonadotropins and their application to the comparison of in vivo and in vitro effects of sex steroids. Gen. Comp. Endocrinol. 2007, 153(1-3):333-343.

27. Pfaffl MW: A new mathematical model for relative quantification in realtime RT-PCR. Nucleic Acids Res. 2001, 29(9):e45.

28. Davison AJ: Comparative analysis of the genomes. In Human Herpesviruses: Biology, Therapy, and Immunoprophylaxis. 2011/02/25th edition. Edited by Arvin A, Campadelli-Fiume G, Mocarski E, Moore PS, Roizman B, Whitley R, Yamanishi K. Cambridge: Cambridge University Press; 2007.

29. van Beurden SJ, Leroy B, Wattiez R, Haenen OL, Boeren S, Vervoort JJ, Peeters BP, Rottier PJ, Engelsma MY, Vanderplasschen AF: Identification and localization of the structural proteins of anguillid herpesvirus 1. Vet. Res. 2011, 42(1):105.

30. van Beurden SJ, Forlenza M, Westphal AH, Wiegertjes GF, Haenen OL, Engelsma MY: The alloherpesviral counterparts of interleukin 10 in European eel and common carp. Fish Shellfish Immunol. 2011, 31(6):1211-1217.

\section{Submit your next manuscript to BioMed Central and take full advantage of:}

- Convenient online submission

- Thorough peer review

- No space constraints or color figure charges

- Immediate publication on acceptance

- Inclusion in PubMed, CAS, Scopus and Google Scholar

- Research which is freely available for redistribution

Submit your manuscript at www.biomedcentral.com/submit 